\title{
Stage IIIa cancer of the right lung ingrowing via right lower pulmonary vein to the left heart atrium
}

\author{
Piotr Błasiak ${ }^{1}$, Paweł Kwinecki ${ }^{3}$, Grzegorz Kacprzak², Konrad Pawełczyk ${ }^{1}$, Marek Marciniak ${ }^{1}$, \\ Małgorzata Winter ${ }^{3}$, Adam Rzechonek ${ }^{1}$ \\ ${ }^{1}$ Department of Thoracic Surgery, Medical University in Wroclaw, Poland \\ ${ }^{2}$ Wroclaw Center for Thoracic Surgery, Lower Silesian Center of Lung Diseases in Wroclaw, Poland \\ ${ }^{3}$ Lower Silesian Center of Heart Diseases "Medinet" in Wroclaw, Poland
}

Kardiochirurgia i Torakochirurgia Polska 2015; 12 (4): 363-366

\begin{abstract}
Computed tomography is performed in every patient before lung tumour resection. The presented case realises how important it is to perform this study with contrast. In a 75-yearold male we detected a tumour ingrowing from the right lung through the right lower pulmonary vein into the left atrium of the heart. The patient was qualified for primary sternotomy with extracorporeal circulation and resection of the intracardiac part of the tumour. In the second stage, right-sided thoracotomy was performed, and right lower lung lobectomy was done. Mixed heterogeneous lung cancer was diagnosed (squamous cell and non-small cell endocrine) in stage IIla. The perioperative period was uncomplicated. The patient, due to renal failure, was not eligible for adjuvant chemotherapy. If the patient were qualified for lobectomy based directly on computed tomography without contrast, there would have been a high risk of perioperative death due to embolic incidents and heart failure. Effective multidisciplinary collaboration allowed us to avoid this sort of complication.

Key words: lung cancer, cardiac tumour, heart failure.
\end{abstract}

\section{Introduction}

A 75-year-old male heavy smoker came to our Lung Diseases Centre. He reported chronic non-productive cough, weakness for the preceding three weeks, loss of appetite, and weight loss of about ten kilograms in six months. The interview and the medical history documentation indicated that he was suffering from diabetes type 2, paroxysmal atrial fibrillation, hypertension, chronic renal failure grade 3 , and from generalised atherosclerosis. At age 45 he had undergone resection of the bladder papilloma and cholecystectomy due to cholecystitis. We performed a chest X-ray and found a lung tumour (Fig. 1). In computed tomography (CT) it was located in segment 6 of the right

\section{Streszczenie}

Tomografia komputerowa jest wykonywana u każdego pacjenta przed leczeniem operacyjnym guza płuca. Przedstawiony w pracy przypadek uświadamia, jak ważne jest wykonanie tego badania z kontrastem. U 75-letniego mężczyzny stwierdzono guz wrastający z prawego płuca przez prawą żyłę płucną dolną do lewego przedsionka serca. Pacjenta zakwalifikowano do sternotomii z wykorzystaniem krążenia pozaustrojowego i resekcji wewnątrzsercowej części guza na pierwszym etapie. Następnie wykonano torakotomię prawostronną i resekcję dolnego płata płuca prawego. Rozpoznano mieszaną heterogenną postać raka płuca (płaskonabłonkowego i niedrobnokomórkowego z komponentą raka endokrynnego) w stadium Illa. Przebieg okołooperacyjny był niepowikłany. Pacjenta z powodu niewydolności nerek nie zakwalifikowano do chemioterapii adiuwantowej. Gdyby chory został zakwalifikowany do zabiegu na podstawie badania tomografii komputerowej bez kontrastu, istniałoby duże ryzyko zgonu okołooperacyjnego z powodu incydentu zatorowego bądź niewydolności serca. Efektywna multidyscyplinarna współpraca umożliwiła uniknięcie tego typu powikłania. Słowa kluczowe: rak płuca, guz serca, niewydolność serca.

lung, with diameter of $4.5 \mathrm{~cm}$ and lysis in the centre. In addition, the $\mathrm{CT}$ revealed in the enlarged lower pulmonary vein and in left atrium of the heart an hourglass-shaped structure with dimensions $5.4 \times 1.6 \mathrm{~cm}$. It extended to the periphery of the pulmonary vein branch and sixth segment. The radiologist suggested the presence of neoplasmatic spigot, thrombus, or myxoma. There were no enlarged lymph nodes in the chest CT. The results of laboratory tests of serum revealed the elevation of D-dimers $(791 \mathrm{ng} / \mathrm{ml})$ and C-reactive protein concentration ( $37 \mathrm{mg} / \mathrm{l})$. In bronchofiberoscopy we did not notice any anatomical changes. The bristled biopsy taken from RB6 was negative. We performed a transoesophageal ultrasound heart examination.

Address for correspondence: Piotr Błasiak MD, Department of Thoracic Surgery, Medical University in Wroclaw, 105 Grabiszyńska St., 53-439 Wroclaw, Poland, phone: +48 600077 856, e-mail: blasiakpiotr@gmail.com 

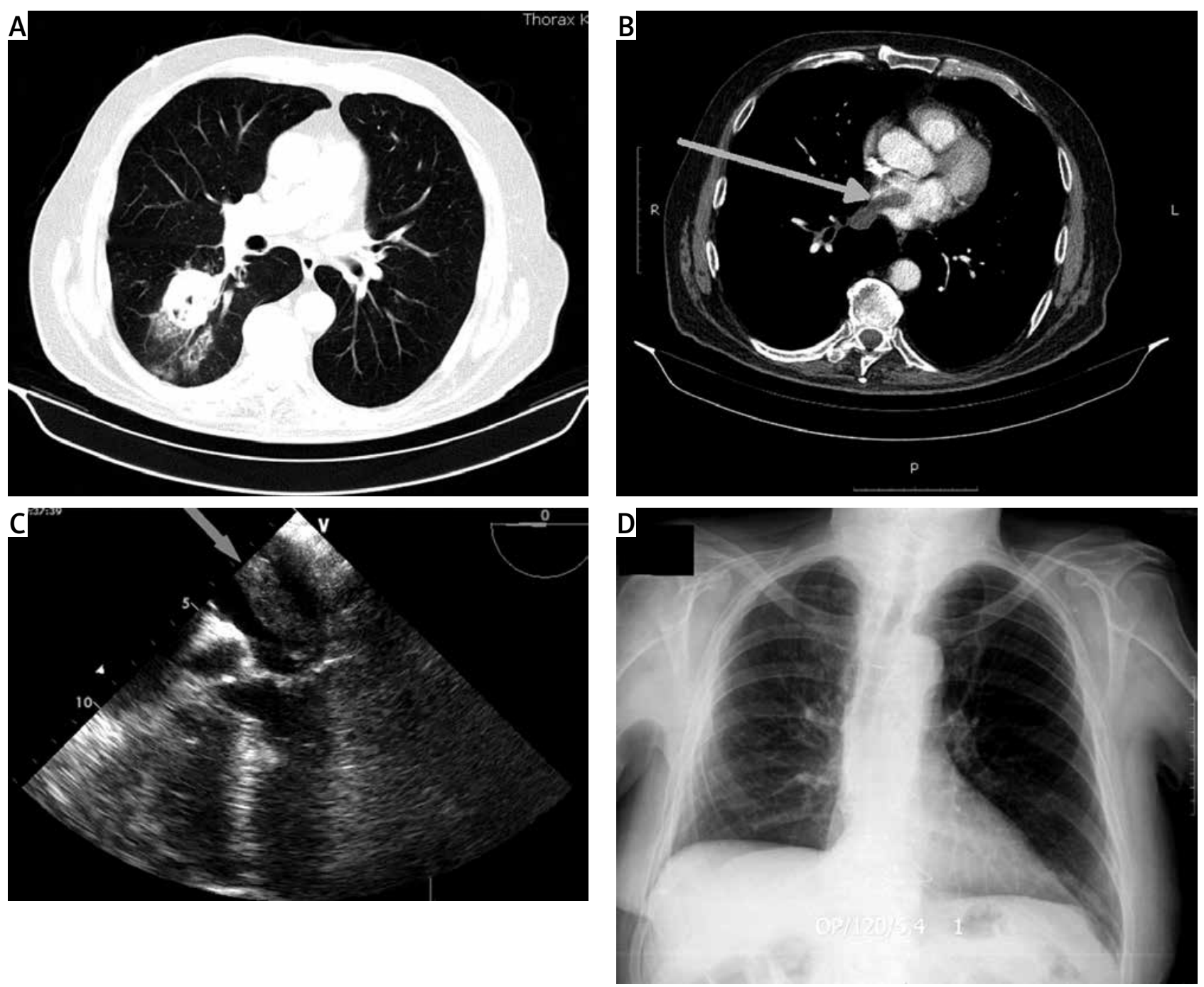

Fig. 1. A) Computed tomography scan with the right lung tumour. B) The loss of contrast in the left atrium and thickening of the pulmonary vein. C) Transoesophageal echocardiography - grey arrow shows intracardiac part of the tumour. D) Radiography after right lower lobectomy

In the left atrium light the additional longitudinal echo ranging from right pulmonary vein ostia to the mouth of mitral valve was recorded - the image corresponded to the character of tumour, thrombus, or myxoma.

\section{Material and methods}

After cardiothoracic consultation the patient was qualified for surgery. In the first stage sternotomy with extracorporeal circulation was performed. We incised the left heart atrium and revealed a pale pink tumour, which we removed completely from the atrium and from the final section of the right lower pulmonary vein.

In intraoperative cytology of the tumour imprints the pathologist found non-small cell lung carcinoma cells. We decided to perform a right-sided thoracotomy in the second stage with right lower lung lobectomy and mediastinal lymphadenectomy. The resected material was sent for histopathological examination. In Figure $2 \mathrm{C}$ the incised right pulmonary vein is shown with its wall infiltration forming the beginning section of the cardiovascular part of the tumour.

\section{Results}

In the final examination of the tumour the pathologist diagnosed mixed heterogeneous lung cancer (squamous cell and non-small cell endocrine) in stage Illa. Postoperative course was without complication. The patient, due to renal failure, was not eligible for adjuvant chemotherapy. The patient is still alive 18 months after surgery.

\section{Discussion}

The most common secondary heart tumour is lung cancer [1]. There are very few cases of lung cancer extension via the pulmonary vein into the left atrium of the heart $[2,3]$. They can be diagnosed by use of transoesophageal echocardiograms, magnetic resonance imaging, and $\mathrm{CT}$ scan [1,3]. Most of those tumours show rapid growth and comprise a large mass in the lung parenchyma [2]. Resection of the intra-atrial mass seems to be a life-threatening procedure because the patient may die from cardiac inflow obstruction and sudden cardiac arrest or massive tumour embolism involving the major organs $[2,4,5]$. The possibil- 

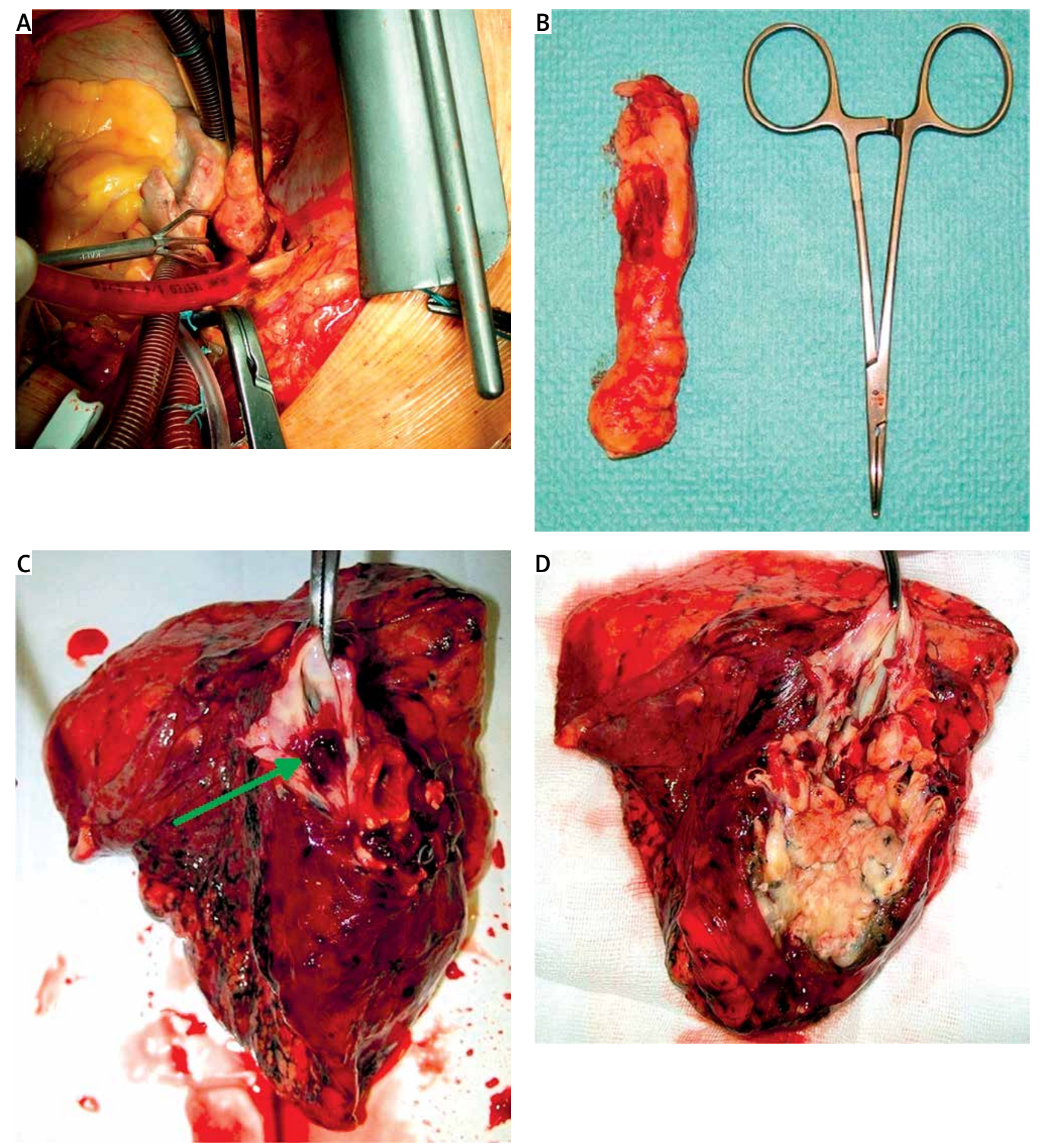

Fig. 2. A) Intracardiac part of the tumour just before the resection and (B) just after the resection. C) Right lower lobe - the pulmonary vein is cut and the infiltration of the vein wall is shown. D) Right lower lobe with the parenchymal part of the tumour

ity of systemic tumour embolisation should be considered in patients with large, central tumours and particularly those that abut the pulmonary veins $[4,5]$.

\section{Conclusions}

Computed tomography with contrast allows the detection of the spread of lung cancer through the vessels into the heart cavity [1]. Malignant lung tumours penetrating into the cavity of the heart can be, in some cases, radically removed. In this case, the tumour did not infiltrate the left atrium of the heart but only grew into its light through the lower pulmonary vein (IIla - T3N1MO - stage). According to this, we determined the TNM as T3N1MO - not T4.

Considering the rapid progression of the tumour in the presented case (the floating part of the tumour in the atrium grew $1 \mathrm{~cm}$ in a week, as seen by comparing ultrasound 
examinations of the heart) rapid multidisciplinary collaboration of the two centres enabled fast and efficient qualification procedure.

\section{Disclosure}

Authors report no conflict of interest.

\section{References}

1. Butany J, Nair V, Naseemuddin A, Nair GM, Catton C, Yau T. Cardiac tumours: diagnosis and management. Lancet Oncol 2005; 6: 219-228.

2. Kodama K, Doi O, Tatsuta M. Unusual extension of lung cancer into the left atrium via the pulmonary vein. Int Surg 1990; 75: 22-26.

3. Brandt RR, Rubin J, Reeder GS. Intracardiac extension of a lung tumor causing left ventricular inflow obstruction. J Am Soc Echocardiogr 1995; 8: 930-933.

4. Whyte RI, Starkey TD, Orringer MB. Tumor emboli from lung neoplasms involving the pulmonary vein. J Thorac Cardiovasc Surg 1992; 104: 421-425.

5. Heslin MJ, Casper ES, Boland P, Gold JP, Burt ME. Preoperative identification and operative management of intraatrial extension of lung tumors. Ann Thorac Surg 1998; 65: 544-546. 